\title{
BERBER ARCHITECTURE AND SUSTAINABILITY: THE PALACES OF THE CITY OF TATAOUINE AS A MODEL
}

Rasha Bin ABD EL JALIL *

Architecture Department, University De Sousse, Tunisia

\begin{abstract}
Tunisia repletes with several types of local architecture. We can enumerate some examples such as the "Manzel architecture " in Djerba, nomad architecture in Nefzaoua, the Djerid Architecture in both Nefta and Tozeur and the q sour architecture situated between Mednine and tataouine. This type of architecture is considered one component of the architectural and cultural opulence which makes the difference between the regions since it is designed from the womb of nature where it is embedded. It takes into account the nature characteristics, the cultural economic and even religious facts.
\end{abstract}

\section{Keywords}

Berber Architecture, Sustainability, Palaces, Tataouine, Tunisia.

\section{Introduction}

We will interest tothe architectural artistic and archeological study of the qsour of Tataouine which are located in the eastern south of Tunisia and they are built in XI century by the Berbers to face bani Hilal tribes. They used them as shelter and storehouses for their agricultural harvests. They are about 150 qasrsdivided into 3 types: 1- the fortressqsour, 2the mountain qsour 3- the plane qsour. Each type of them has its own defensive or basically economic and social function. Some of these qsour were demolished and no longer exist, others are restored and included with touristic path in the region such as qasr Hadada and some of them are turned into festivals.

This research will deal with two basic topics. First we will deal with the architectural study of those qsour. Secondly we'll try to find how to evaluate this ancient architecture which proved their resistance over the centuries and their adoption to this saharian environment which made of them an everlasting architecture.

The governorate of Tataouine is located in the far south-eastern Tunisia of Tunisia, and it is a Berber region and occupies an area of approximately one third of the Tunisian country. In Berber, its name means "ElAyoun" and its terrain varies, as there are plains, mountains, and the vast desert. It is bordered by the Al-Zahir mountain range and the Matmata Mountains on the western side. As a result of this terrain, there are many valleys and streams of reefs. As for the eastern side, it is arid and suffers from a shortage of water. This region is characterized by a desert climate and a high temperature range, and the amount of rain ranges between 106 and $200 \mathrm{~mm}$. As for the stability that covers this spring, it is mainly represented in the cultivation of grains, olive trees, some vegetables and fruit trees, such as two for example. The agricultural activity is also based on livestock raising, some traditional industries, tourism and fishing.

The population of this region is a homogeneous mixture of Berbers and Arabs. As for the Berbers, who are the original inhabitants of the region and are residing in the tribes of Douirat, Chianti, Qatufa and Ghamrasniyya. As for the Arab race, they are crescent Arab tribes who came to this region via the Jaffara plain in the eleventh century. They are the tribes of Wadarneh and the tribes of Ajarda, Daghagharah, al-Muqala and alDhibat. There is also the Glaidat tribe, an Arab from the Idrisids who settled in Tunisia and coming from the Far

* Corresponding author: ijmsat.info@gmail.com 
Maghreb. The Arabs were interested in their economic activities, raising livestock and poultry. As for the Berbers, they controlled the agricultural activity. Berbers are the urban peasants who inhabit the mountainous heights. As for the Arabs, who are the residents of Al-Hol, they are kicked shepherds. And this theory confirmed the colonial reading of the region. The Amazighs sought refuge in the mountains at the arrival of the Bani Hilal hordes, and took them as a fortress and a refuge. They also controlled the passages and strategic locations between the mountains of al-Zahir and the plains of Jafara. As for the Arabs, they took the plains for their pastures and their travels.

But it should be noted that the reason for resorting to the mountains is not only political, but has economic motives, and the higher regions are more fertile and more watery and their climate is more moderate. These Berbers did not abandon their position in the mountains even after the Arab influence diminished, which indicates that the choice of the mountain was wise and correct.

The city of Tataouine was known for its ancient history through many periods. Prehistoric stations were discovered in the Ain Doukk Valley and Douirat. The most important of these prehistoric stations are those located in the depths of Ghamrasen, which are the station "Ansafari" and the energy Hamed "and" Division of Battle ", which is a phrase on caves dating back five thousand years in which primitive drawings of the daily life of the inhabitants of the region were drawn. This ancient region witnessed the arrival of the Phoenicians, the Romans, the Vandals, the Byzantines and finally the Arabs. The southeastern region represents the touch line that separates the northern regions dominated by Rome and the southern borders. These have left many monuments, especially the Roman ones in the mountainous regions, so we find many water installations The ruins of which have remained to this day, and facilities with a defensive character, such as the fortress of Tilal and the fortress of Remada, and it seems that the first palaces in this region were built close to these monuments, and it is worth saying also that the relationship between the occupier and the indigenous population ranged between submission and wars. Free Men) were against any outside element.

With the advent of the Arabs, which had been since the Islamic conquest in the seventh century AD, then with the advent of the Hilalis, the inhabitants built fortresses and fortresses in which they sheltered from the invaders. As for the Arab component, it welcomed them in this region and relatively abandoned the journey, and it formed in the first stage the mountain palaces and then the plain palaces at a later stage. Palaces became the basic nucleus around which economic life was centered.

\section{Analytical Study of Tataouine Deficiency}

\section{The Concept of Deficiencies}

It differs from the concept of the usual palace i.e. power and influence. It is a traditional architecture used by the community for various life purposes. Palaces spread in the states of Tataouine and Medenine. It extends from the mountain range of Daher, which starts from the south of Gabes towards Medenine and Tataouine. This mountain range, which extends to the heights of Nafusa, forms a crescent-shaped barrier between the sea and the Jafara Plain on the one hand and the desert that occurred in the south on the other.

The palace is the first vital center around which life originates and develops. It is an economic, defensive and social institution. The palace is also a ruin or a castle, with some differences between these terms. The palace and its collection, kasour, is a group of warehouses in which agricultural materials (oil, grains, figs, iron ...) are hidden. And these materials can be stored for a long period of up to seven years in order to avoid years of drought and the theft of crops from the hostile tribes while traveling. The citadel or fortress was designed for a defensive 
purpose. And Khirbet means the palace that mattered and disappeared. Both the palace and the castle are subject to the same architectural design. They are on an open courtyard surrounded by a group of rooms that have spread over several floors historically. Some of these palaces were built prior to the crescent existence, as they date back to the Roman era or the first Islamic period.

In addition to the storage function of agricultural resources, palaces also play a social role, as they are transformed into social life because it is a space in which tribe members meet to consult on matters of the tribe, for example and in economic exchange. The courtyards of these palaces developed weekly markets in the plains for a later period. These palaces are considered among the important architectural evidence that indicates the extent to which a person has adapted to this difficult environment, and these palaces have become attracting many tourists from inside or outside the country and some desert festivals are held there.

\section{Types of Deficiencies}

Urbanism spreads around these palaces. The palace overlooks the villages that were formed around it, especially if the palace was located high in the mountains. In addition, there are isolated palaces on the neighboring villages, which are mostly plain palaces or mountain palaces. The latter is characterized by the presence of the inner courtyard, which plays the role of a space for meeting and for commercial exchange and as a place for animals. And expansion takes place within the palaces due to the abundance of agricultural production or the increase in tribe members. And this expansion is the basis within these spaces by adding upper floors that can reach five floors, or in the yard. These palaces become roads due to these multiple expansions, and the square loses its first area.

\section{Minors Components}

Whatever the type of palace, it is organized according to the following architectural components: the entrance, the courtyard, the metaphor, the composition, the amphitheatres, and finally the room. The palace is subject to the same organization of the old Roman house or the Mediterranean house, as this architecture opens to the interior and all its components are organized around the courtyard. And this model is compatible with the natural and climatic characteristics of the region as well as with the social customs and rituals of the region.

The entrance: the palace usually has one door. It is a double-leafed wooden door made of aliton or vinegar logs. The main façade is made of stone, which is mostly solid. The outer door leads to a shed with dimensions not exceeding $3 \mathrm{~m}$ in width. And above the shed and the room of the guard in charge of protecting the palace, and the interior space of the shed is usually equipped with stone floors.

The courtyard: the shed leads to the courtyard, which takes different shapes and dimensions and is rectangular, square or elliptical. It is a space for the distribution of rooms and a litter for the doors that come loaded with agricultural crops. It is also used for commercial exchanges and meetings. In the courtyard space, expansion is made by adding a number of rooms if the need arises.

Al-Majaz: It is the corridor that distributes rooms. The width of the metaphor varies according to the type of palace. Its width in castles is less than two meters and widens in the palaces of the hills, up to 3 meters, and the narrow or wideness of the metaphor determines the extent of the extension of the shadow or receding.

Runways and staircases: Runways were included in the architectural components of the palace in the late nineteenth century, and their dimensions differ from the runways designed by an architect. Their height is irregular, and they are stone and coated with lime mortar. As for the breeding, it is a stone jutting out vertically in the wall used to ascend to the upper rooms. The doors of the upper rooms are surmounted by wooden poles called 
"hangers," and ropes are drawn to them to raise agricultural materials and store them in the upper rooms. In front of each room there is a small stone rest.

The room: It is the main storage space and the basic palace unit. And they are organized like hives. A single palace can include many types of rooms, whose dimensions and configuration differ according to the stored agricultural materials. It can decorate the room with two arcs on the sides or with one arch, and the rooms can also be prepared with a pillow or khkhtabh. The rooms of the upper floors are also characterized by their simplicity and are of late construction. The depth of the room ranges between 3-8 $\mathrm{m}$. One-floor rooms can be connected to form a maze that is difficult to penetrate or steal their savings. Small cups are opened in these rooms to ventilate the rooms and preserve the health of the stored foodstuffs.

A blacksmith or carpenter's shop: it is customary to open a blacksmith or trade store adjacent to the palace in order to enable farmers and palace exploiters to repair their agricultural equipment or some of the palace locks and so on. A blacksmith's palace, an example of this, is still to this day a blacksmith's shop.

\section{Structural Materials}

They are local materials coming from the neighboring heights, which gives this architecture a unique elegance and character.

\section{Stone}

Palaces were built from monolithic stones brought from nearby areas, and were devoid of decency. It is limestone, which is used according to its nature or burned to form, in a later period, a mortar to connect these stones. The walls are erected on solid rock floor and the stones are bonded with lime mortar. Also, vaulted ceilings that cover the rooms are built with stones bonded with lime mortar. Among the other architectural components of the stone, we mention the lower runways in particular and the rest that is set up in front of the upper rooms, which rest on wooden mansions. The paving of the courtyard is also made using flat stones.

\section{Myth}

The decoration is limited to the ceilings of the vaulted rooms and the lintels of the main doors. The elements of the craft mainly consist of broken lines, points, triangles, five (the hand), the foot ... and have multiple symbolic connotations. The same elements are also employed in the decoration of wool carpets, in tattoos, in jewelry ... etc. Hand drawing, for example, and like some other drawings has deep symbolism in popular pictures. This hand or five symbolizes the five rules of Islam, but it especially symbolizes the removal of the evil eye and envy. The use of points also symbolizes, according to the account of one of the users of Shani Palace, the amount of agricultural stock that each family owns that divides this palace.

Among the mythical elements that decorate the domes and the inner walls of the palaces are geometric shapes of lozenges, circles, stars, and some imaginary papers. This decorative art does not contain prophetic elements (flowers, rosettes or branches) and is not subject to symmetry and repetition as is the case with ArabIslamic art.

\section{Conclusion}

The governorate of Tataouine is rich in many architectural evidence that tells us about hundreds of years of history. There were many styles of architecture, from one on the heights of the heights to another on flat lands. And these areas were inhabited by the Berbers, meaning the indigenous people, and the Arabs. We cannot really separate these two sexes, since there are Berber tribes that took over the mountainous regions. 
These palaces, the subject of our study, are a model of traditional local architecture that identifies with the mountainous nature that emanates from it. They are villages built using their stones and taking into account the climatic and living characteristics of the region, so it was a sustainable architecture par excellence that was able to preserve the agricultural products for a long time and to discourage its function and its architectural aesthetics. This architecture has proven its efficacy since pre-Christian times. For example, we mention the Tower of Babel, which dates back to the seventh century B.C., or the architecture of Yemen, which is still standing today. For this construction, simple techniques and tools were used.

But these palaces remained a station until they almost become ruins and disappear. It did not keep pace with the development of modern life, which turned to modern construction materials, and this was without awareness and without thinking about the consequences of this trend, which proved incompatible with the environmental, social and economic characteristics.

The building model, which opens inside to singing, the solid exterior walls, and the use of stones and lime mortar, create favorable internal climates, unlike the red jaguar and reinforced concrete and the large openings that deformed this area.

We agree with the architect, Hassan Fathy, the Egyptian engineer, owner of the new Gourna project, in his vision that it is not possible to build an eastern house in Europe or a house on the western model in Arab countries, due to the inconsistency of all the data. Both examples seem to have fallen into the new environment.

How can this architecture keep pace with the developments of modern life and emerge from its negative rigidity without ignoring the natural, architectural, social, cultural and economic characteristics of the region? And what are the mechanisms that can be adopted to advance it?

\section{References}

1- Ammar, 1, histoire de l'architecture en tunisie, cpu, 2010.

2- Ben quezdou, h., découvrir la tunisie du sud. De matmata àtataouine : ksour, jessour et troglodytes, tunis, 2001.

3- Louis, a., tunisie du sud, ksars et villages de crêtes. Paris : c.n.r.s, 1975.

4- Louis, a., « douiret : étrange cité berbère ». Tunis, std, 1975.

5- Zaied a., le monde des ksour au sud tunisien, tunis, centre de publication universitaire, 2006.

6- Khatalli, h, sghaier, m,sandron, $\mathrm{f}$, « le village berbère de chenini (sud-est tunisien) : richesse d'un patrimoine fragilisé », in revue des régions arides $n^{\circ} 38(3 / 2015)$ en ligne. Http://horizon.documentation.ird.fr/exldoc/pleins textes/divers 1702/010069128.pdf .

7- Laroussi k., le gsar : vestige de temps nomades. Revue des régions arides(numéro spécial)-actes de l'atelier « diversité du patrimoine culturel et naturel dansle sud-est tunisien : problématique de la conservation/valorisation, p 4797. Https://www.academia.edu/25964249/le gasr_vestige des tempsnomads

Received: February 3, 2018

Accepted: April 5, 2018 